\title{
White Matter Hyperintensities and Cerebral Microbleeds in Ataxia-Telangiectasia
}

May Yung Tiet, MBChB, MSc, Stefania Nannoni, MD, PhD, Daniel Scoffings, MBBS, Katherine Schon, BM BCh, Rita Horvath, MD, PhD, Hugh Stephen Markus, DM, FMed Sci, and Anke Erma Hensiek, FRCP, PhD

Neurol Genet 2021;7:e640. doi:10.1212/NXG.0000000000000640

\section{Abstract}

\section{Background and Objectives}

To systematically assess the occurrence of cerebral microbleeds (CMBs) and white matter hyperintensities (WMHs) in the largest published cohort of adults with ataxia-telangiectasia (AT).

\section{Methods}

We assessed 38 adults with AT (age range 18-55 years) including 15 classic and 23 variant AT, evaluated by two independent assessors. WMHs were quantified on T2-fluid attenuated inversion recovery images using the semiquantitative modified Scheltens and Fazekas scales and $\mathrm{CMB}$ on susceptibility-weighted imaging and $\mathrm{T} 22^{*}$-weighted gradient echo sequences using the Brain Observer MicroBleed Scale.

\section{Results}

CMBs were more frequently found in classic AT compared with variant AT (66.7\% vs 5.9\%) predominantly in cortical and subcortical regions. WMHs were seen in $25(73.5 \%)$ probands and CMBs in 9 (31.0\%). The burden of WMHs increased with age, and WMHs were focused in periventricular and deep white matter regions. WMHs were more frequently seen in variant than classic AT.

\section{Discussion}

This cohort study confirms that WMHs and CMBs are a frequent finding in AT. Further longitudinal studies are required to understand how WMHs and CMBs relate to the neurodegeneration that occurs in AT and the predisposition to cerebral hemorrhage.
Correspondence

Dr. Hensiek

ahensiek@nhs.net

From the Department of Clinical Neurosciences (M.Y.T., S.N., K.S., R.H., H.S.M.), University of Cambridge; Department of Radiology (D.S.), Addenbrooke's Hospital; and National Clinic for Ataxia Telangiectasia, Papworth Hospital NHS Foundation Trust (A.E.H.), Cambridge, United Kingdom.

Go to Neurology.org/NG for full disclosures. Funding information is provided at the end of the article.

The Article Processing Charge was funded by the Wellcome Trust.

This is an open access article distributed under the terms of the Creative Commons Attribution License 4.0 (CC BY), which permits unrestricted use, distribution, and reproduction in any medium, provided the original work is properly cited. 
Ataxia-telangiectasia (AT) is a rare autosomal recessive neurodegenerative DNA repair disorder that results in cerebellar ataxia and extrapyramidal symptoms. ${ }^{1}$ Although visceral telangiectasia-associated hemorrhages have been reported in $\mathrm{AT}$, vascular abnormalities in the brain have not been systematically assessed.

Isolated small-scale studies suggest the presence of white matter hyperintensities (WMHs) and cerebral microbleeds (CMBs) in AT; both are associated with worse clinical outcomes in other neurodegenerative disorders, such as $\mathrm{Alz}$ heimer disease. ${ }^{2}$ It is important to identify potential cerebrovascular abnormalities in AT and how they relate to neurodegeneration. Here, we systematically analyzed our AT cohort for WMHs and CMBs.

\section{Methods}

From the Cambridge adult cohort, 38 subjects with confirmed AT (15 classic and 23 variant, age $18-55$ years, 16 male and 22 female) underwent brain MRI scanning and were assessed for vascular risk factors and immunodeficiency (Figure 1). Two investigators independently analyzed T2-fluid attenuated inversion recovery for WMHs using the Fazekas and modified Scheltens score to quantify burden overall and individual brain regions. ${ }^{3}$ Susceptibility weighted imaging or $\mathrm{T} 2{ }^{*}$-weighted gradient echo sequences were reviewed for probable CMBs using the Brain Observer MicroBleed Scale. ${ }^{4}$ Images were excluded if movement artifact prevented systematic analysis.

Informed consent was obtained (13/YH/0310). Statistical analysis (Fisher exact and Mann-Whitney) was performed using GraphPad Prism 9.1.

\section{Data Availability}

Anonymized data and documentation of this study will be shared on reasonable request from any qualified researcher. Standard data sharing agreements apply.

\section{Results}

\section{Microhemorrhages Are More Frequent in Classic AT}

Twenty-nine subjects (12 classic and 17 variant) were included in the CMB analysis. Nine subjects were excluded because of motion artifact or no susceptibility weighted imaging. CMBs were more commonly seen in classic AT $(8[66.7 \%]$ vs $1[5.9 \%][p<0.01$, OR $32.0, \mathrm{CI}$ 3.17-369.8]). CMBs were commonly seen in cortical and subcortical regions rather than cerebellar and basal ganglia (Figure 2B).

Three subjects with classic AT had extensive CMBs (>100) (Figure 1). One patient who had extensive CMBs died of an intracerebral hemorrhage ( $\mathrm{ICH})$.

\section{White Matter Hyperintensities in AT}

Thirty-four subjects (12 classic and 22 variant AT) were assessed for WMHs. Three probands were excluded because of motion artifact or lack of fluid attenuated inversion recovery sequencing and 1 because of extensive cerebral edema. Our subjects had only mild WMHs (Fazekas: mean 0.32, range 0-1, SD 0.47; modified Scheltens criteria: mean 2.29, range $0-11, \mathrm{SD} 2.46$ ).

WMH (Figure 1) was more frequent in variant AT $(81.8 \%$ vs $58.3 \%$ classic, $\mathrm{n}=18$ and 7 , respectively) but was not statistically significant ( $p=0.224$, OR $0.311,95 \%$ CI 0.079-1.634). $\mathrm{WMH}$ burden increased with age (not shown) and was predominantly extracerebellar (Figure 2A).

\section{Genotype-Phenotype Correlations}

A common leaking splice site variant was present in $26.1 \%$ (n =6) subjects with variant AT, c.5763-1050A > G; p.Pro1922fs. No distinguishing phenotype was noted, but no patients with this variant had a CMB. A total of 8 subjects had cancer, and the presence of $\mathrm{WMH}$ was not associated with chemotherapy use (eTable 1, links.lww.com/NXG/A491).

Figure 1 White Matter Hyperintensities (Left) in a Patient With Variant AT at Age 22 Years; Cerebral Microbleeds (Right) in a Patient With Classic AT at Age 23 Years.

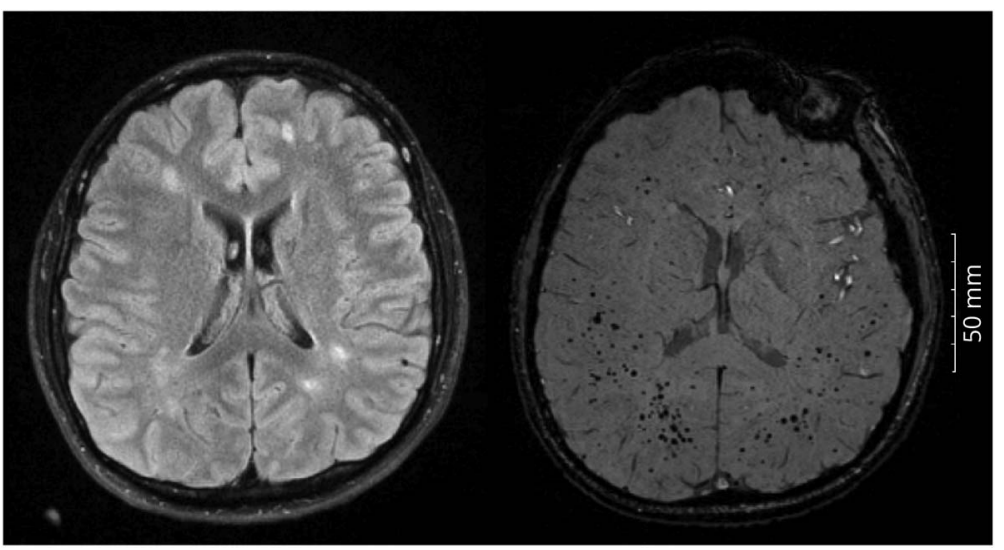


Figure 2 Heatmap Showing the Distribution of $(A)$ White Matter Hyperintensities in Subjects With AT (Classic $n=12$ and Variant $n=22$ ). (B) Cerebral Microbleeds in Subjects With AT (Classic $n=12$ and variant $n=17)$

A

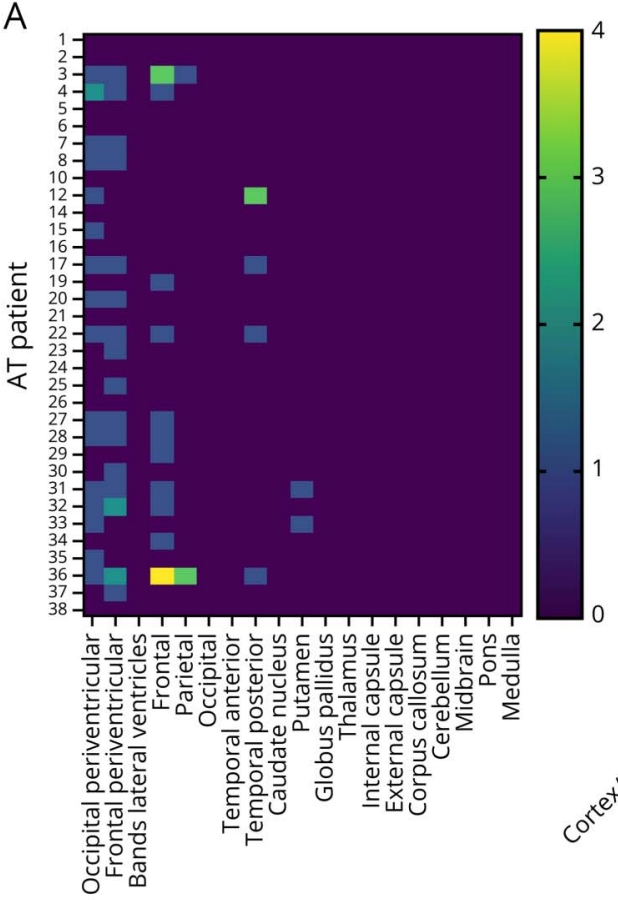

Location of WMH
B

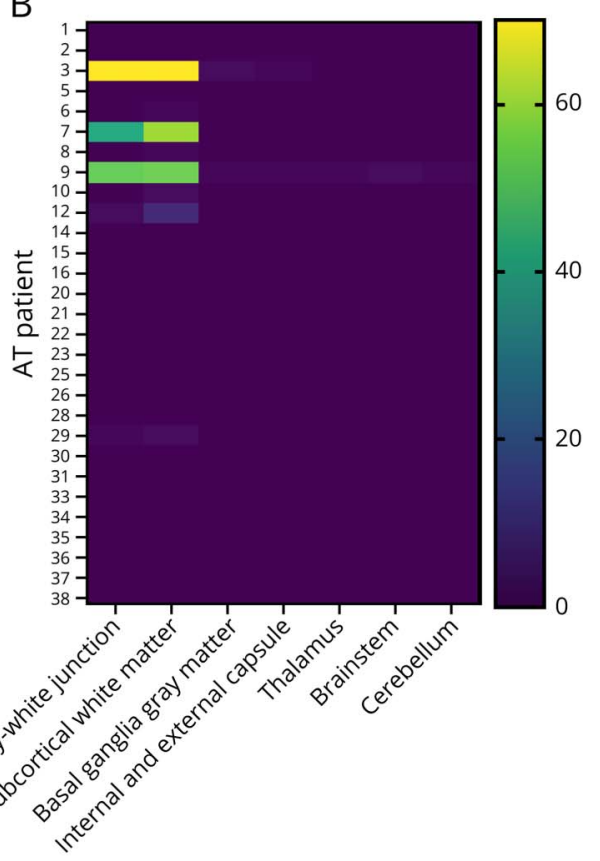

The average age was 21.4 years for classic $(\mathrm{n}=15)$ and 35.8 years for variant AT $(n=23)$ (Table). The body mass index, diabetes, and hypercholesterolemia were not significantly associated with WMHs or CMBs. Fatty liver was seen in $81.8 \%$ of classic $(\mathrm{n}=9)$ vs $16.7 \%$ of variant AT $(\mathrm{n}=3)$ and was significantly associated with the presence of CMBs $(p<0.01$, OR 21.0, CI 1.856-250.8) but not WMHs ( $p=0.358$, OR 0.359 , CI 0.056-2.189).

\section{Conclusions}

We report that $\mathrm{CMBs}$ are common and sometimes extensive in classic AT but mainly extracerebellar. In contrast, individuals with milder variant AT had a higher proportion of WMHs with a lower incidence of CMBs. However, WMH burden was overall mild, and the mechanism is unknown.

It is possible that CMBs result from small vascular abnormalities, i.e., telangiectasia, such as those seen in the viscera. This is supported by the fact that ocular telangiectasia is usually present in classic AT, but not necessarily in variant patients. An alternative proposed mechanism of white matter edema in AT are transudates or exudates from leaky vessels. ${ }^{5}$ These leaky, more fragile vessels could predispose to hemorrhage. Previous autopsies found vascular abnormalities with spongy degeneration surrounding vessels in the cortex. ${ }^{6}$
WMHs and CMBs are markers of small vessel disease in other neurodegenerative disorders. ${ }^{2}$ As this is a retrospective analysis, we acknowledge the limitations of lack of control data. Further studies are required to understand the clinical implications and origins of CMBs. CMBs are a known risk factor for impaired cognitive function and increase in incidence with age. ${ }^{2}$ However, an incidence of $61 \% \mathrm{CMBs}$ in young patients admitted with $\mathrm{ICH}$ has previously been reported. ${ }^{7}$

Clinicians need to be aware of the high proportion of CMBs in classic AT, which predisposes patients to ICH. Anticoagulation should ideally be avoided in these cases. Further studies will be required to evaluate the association between $\mathrm{WMH}, \mathrm{CMB}$, and AT neurodegeneration.

\section{Acknowledgment}

The authors thank Matthew James Jennings for his advice regarding statistical analysis.

\section{Study Funding}

M.Y. Tiet is supported by the Addenbrooke's Charitable Trust (G103290). R. Horvath is a Wellcome Trust Investigator (109915/Z/15/Z), who receives support from the Medical Research Council (UK) (MR/N025431/1 and MR/V009346/ 1), the Newton Fund (UK/Turkey, MR/N027302/1), the Evelyn Trust, the Stoneygate Trust, the Lily Foundation, an MRC strategic award to establish an International Centre for 


\begin{tabular}{|c|c|c|c|c|c|c|c|c|c|c|c|c|c|}
\hline \multirow[b]{2}{*}{ Sex } & \multirow[b]{2}{*}{ AT subtype } & \multirow[b]{2}{*}{ Duration of disease $(y)$} & \multirow[b]{2}{*}{ Age at MRI (y) } & \multirow[b]{2}{*}{ BMI } & \multirow[b]{2}{*}{ Smoker (Y/N) } & \multirow[b]{2}{*}{ Diabetes (Y/N) } & \multicolumn{3}{|c|}{ Cholesterol (mmol/L) } & \multirow[b]{2}{*}{ Triglycerides ( $\mathrm{mmol} / \mathrm{L}$ ) } & \multirow[b]{2}{*}{ BP } & \multirow[b]{2}{*}{ Alcohol (Y/N) } & \multirow[b]{2}{*}{ Fatty liver $(\mathrm{Y} / \mathrm{N})$} \\
\hline & & & & & & & Total & HDL & LDL & & & & \\
\hline $\mathrm{M}$ & Classic & 19 & 21 & 22.3 & $\mathrm{~N}$ & $\mathrm{~N}$ & 9.2 & 1.3 & ? & ? & $118 / 65$ & $\mathrm{~N}$ & $\mathrm{Y}$ \\
\hline $\mathrm{M}$ & Classic & 10 & 18 & 20.3 & $\mathrm{~N}$ & $\mathrm{~N}$ & 4.3 & 1.1 & 2.6 & 1.4 & $117 / 56$ & $\mathrm{~N}$ & ? \\
\hline $\mathrm{M}$ & Classic & 20 & 21 & 14.7 & $\mathrm{~N}$ & $\mathrm{~N}$ & 5 & 1.3 & 3.3 & 0.8 & $112 / 66$ & $?$ & $\mathrm{Y}$ \\
\hline $\mathrm{F}$ & Classic & 21 & 23 & 20.2 & N & $N$ & 5.7 & 1.35 & 3.4 & 2.09 & $109 / 79$ & $\mathrm{~N}$ & $?$ \\
\hline $\mathrm{F}$ & Classic & 17 & 18 & 20.4 & $\mathrm{~N}$ & $\mathrm{~N}$ & 4.5 & 1.6 & 2.51 & 0.86 & $103 / 62$ & $\mathrm{~N}$ & ? \\
\hline $\mathrm{F}$ & Classic & 18 & 19 & 18.6 & N & $\mathrm{Y}$ & 6.6 & 1.18 & 4.57 & 1.86 & $127 / 85$ & $\mathrm{~N}$ & $?$ \\
\hline M & Classic & 21 & 22 & 19.8 & N & $\mathrm{N}$ & 7.3 & 0.8 & n.d. & 5.4 & $126 / 75$ & $\begin{array}{l}Y \\
5 u / w k\end{array}$ & Y \\
\hline $\mathrm{F}$ & Classic & 14 & 22 & 16.1 & $\mathrm{~N}$ & $\mathrm{~N}$ & 4 & 1.3 & 2.50 & 0.5 & $120 / 80$ & $\mathrm{~N}$ & $\mathrm{~N}$ \\
\hline M & Classic & 29 & 31 & 20.3 & N & $\mathrm{N}$ & $?$ & n.d. & n.d. & 31.9 & $126 / 82$ & $\mathrm{~N}$ & Y \\
\hline $\mathrm{F}$ & Classic & 18 & 21 & 17.0 & $?$ & $\mathrm{~N}$ & 5.1 & 0.6 & 2.9 & 3.5 & $108 / 75$ & $\begin{array}{l}\text { Y } \\
\text { Rare }\end{array}$ & Y \\
\hline M & Classic & 20 & 20 & 16.1 & N & Y & 7.8 & 0.9 & 5.4 & 3.2 & $106 / 84$ & $N$ & $\mathrm{~N}$ \\
\hline $\mathrm{M}$ & Classic & 19 & 19 & 24.2 & $\mathrm{~N}$ & $\mathrm{~N}$ & 6.8 & 1.4 & 4.6 & ? & $118 / 79$ & $\mathrm{~N}$ & $\mathrm{Y}$ \\
\hline $\mathrm{F}$ & Classic & 17 & 19 & 25.97 & & $\mathrm{~N}$ & 6.0 & 1.2 & 4 & 1.7 & $110 / 90$ & & $Y$ \\
\hline $\mathrm{F}$ & Classic & 21 & 22 & 17.7 & $\mathrm{~N}$ & $N$ & $?$ & 0.6 & 3.2 & 3.8 & $123 / 82$ & $N$ & $Y$ \\
\hline M & Classic & 25 & 25 & 22.1 & $N$ & $N$ & 8.4 & 1.02 & n.d. & 10.93 & $120 / 78$ & $\begin{array}{l}Y \\
2 u / w k\end{array}$ & $\mathrm{Y}$ \\
\hline M & Variant & 18 & 21 & 16.1 & $\mathrm{~N}$ & $N$ & $?$ & 1.8 & 1.4 & 0.6 & $122 / 70$ & $\begin{array}{l}\text { Y } \\
\text { 1-2u monthly }\end{array}$ & $\mathrm{N}$ \\
\hline$M$ & Variant & 21 & 23 & 17.9 & $N$ & $N$ & 3.6 & 1.2 & 1.5 & 1.9 & $147 / 67$ & $\begin{array}{l}\mathrm{Y} \\
2-4 \times / \mathrm{mo}\end{array}$ & $\mathrm{N}$ \\
\hline $\mathrm{F}$ & Variant & 47 & 49 & 36.1 & $N$ & $N$ & 5.5 & 1.5 & 3.3 & 1.6 & $123 / 79$ & $N$ & $N$ \\
\hline $\mathrm{F}$ & Variant & 22 & 23 & 27.2 & $\mathrm{~N}$ & $N$ & 4.6 & 1.2 & 3.1 & 0.6 & $120 / 70$ & $N$ & $\mathrm{~N}$ \\
\hline $\mathrm{F}$ & Variant & 33 & 35 & 29.5 & $N$ & $N$ & $?$ & & & & $118 / 73$ & $\begin{array}{l}\text { Y } \\
\text { monthly }\end{array}$ & $?$ \\
\hline $\mathrm{F}$ & Variant & 32 & 40 & 24.4 & $N$ & $\mathrm{~N}$ & $?$ & 1.4 & 4.3 & 0.8 & $101 / 80$ & $\begin{array}{l}Y \\
4 u / w k\end{array}$ & $N$ \\
\hline
\end{tabular}


Table Participant Vascular Risk Factors, Genotype, and Phenotype (continued)

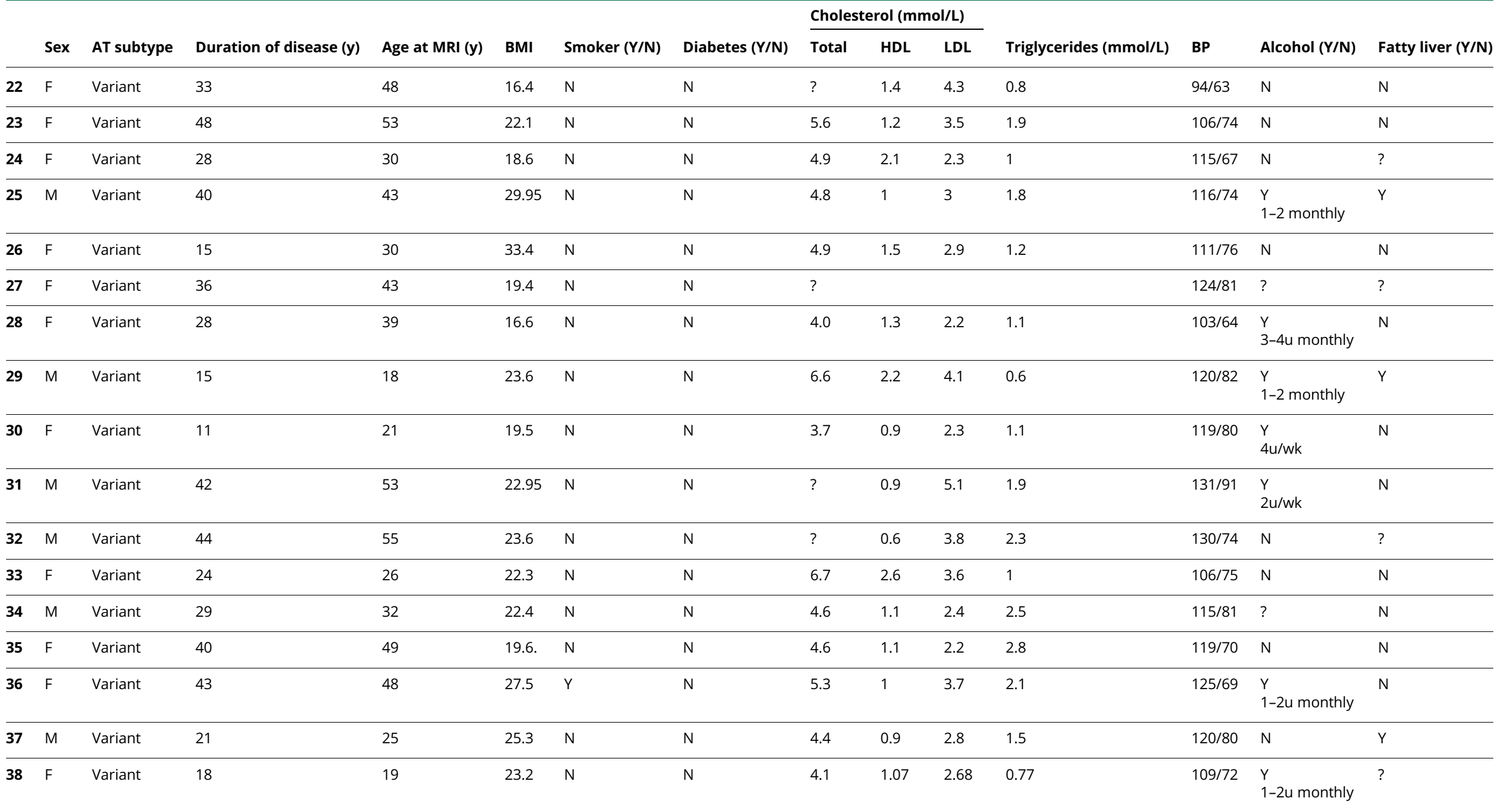

Abbreviations: $A T$ = ataxia-telangiectasia; $B M I=$ body mass index; $H D L=$ high-density lipoprotein; $L D L=$ low-density lipoprotein; $N=$ no; $n . d .=$ not done; $u=u$ units; $Y=$ yes. 
Genomic Medicine in Neuromuscular Diseases (ICGNMD) MR/S005021/1, and Addenbrookes Charitable Trust G100142. H.S. Markus is supported by an NIHR Senior Investigator award. This research was supported by the NIHR Cambridge Biomedical Research Centre (BRC-1215-20014). The views expressed are those of the author(s) and not necessarily those of the NIHR or the Department of Health and Social Care.

\section{Disclosure}

The authors report no disclosures. Go to Neurology.org/NG for full disclosure.

\section{Publication History}

Received by Neurology: Genetics June 14, 2021. Accepted in final form October 7, 2021.

\section{Appendix Authors}

\begin{tabular}{|c|c|c|}
\hline Name & Location & Contribution \\
\hline $\begin{array}{l}\text { May Yung } \\
\text { Tiet, MBChB, } \\
\text { MSc }\end{array}$ & $\begin{array}{l}\text { Department of Clinical } \\
\text { Neurosciences, University of } \\
\text { Cambridge, United Kingdom }\end{array}$ & $\begin{array}{l}\text { Drafting/revision of the } \\
\text { manuscript for content, } \\
\text { including medical writing for } \\
\text { content; major role in the } \\
\text { acquisition of data; study } \\
\text { concept or design; analysis } \\
\text { or interpretation of data; } \\
\text { and additional } \\
\text { contributions: one of the } \\
\text { two investigators for } \\
\text { ranking MRI white matter } \\
\text { hyperintensities and } \\
\text { cerebral microbleeds }\end{array}$ \\
\hline $\begin{array}{l}\text { Stefania } \\
\text { Nannoni, MD, } \\
\text { PhD }\end{array}$ & $\begin{array}{l}\text { Department of Clinical } \\
\text { Neurosciences, University of } \\
\text { Cambridge, United Kingdom }\end{array}$ & $\begin{array}{l}\text { Analysis or interpretation of } \\
\text { data; additional } \\
\text { contributions: one of the } \\
\text { two investigators for } \\
\text { ranking MRI white matter } \\
\text { hyperintensities and } \\
\text { cerebral microbleeds }\end{array}$ \\
\hline $\begin{array}{l}\text { Daniel } \\
\text { Scoffings, } \\
\text { MBBS }\end{array}$ & $\begin{array}{l}\text { Department of Radiology, } \\
\text { Addenbrooke's Hospital, } \\
\text { Cambridge, United Kingdom }\end{array}$ & $\begin{array}{l}\text { Drafting/revision of the } \\
\text { manuscript for content, } \\
\text { including medical writing for } \\
\text { content, and analysis or } \\
\text { interpretation of data }\end{array}$ \\
\hline
\end{tabular}

Appendix (continued)

\begin{tabular}{|c|c|c|}
\hline Name & Location & Contribution \\
\hline $\begin{array}{l}\text { Katherine } \\
\text { Schon, BM } \\
\text { BCh }\end{array}$ & $\begin{array}{l}\text { Department of Clinical } \\
\text { Neurosciences, University of } \\
\text { Cambridge, United Kingdom }\end{array}$ & $\begin{array}{l}\text { Major role in the acquisition } \\
\text { of data; analysis or } \\
\text { interpretation of data; and } \\
\text { additional contributions: } \\
\text { data collection and } \\
\text { genotype-phenotype } \\
\text { correlation }\end{array}$ \\
\hline $\begin{array}{l}\text { Rita Horvath, } \\
\text { MD, PhD }\end{array}$ & $\begin{array}{l}\text { Department of Clinical } \\
\text { Neurosciences, University of } \\
\text { Cambridge, United Kingdom }\end{array}$ & $\begin{array}{l}\text { Drafting/revision of the } \\
\text { manuscript for content, } \\
\text { including medical writing for } \\
\text { content; study concept or } \\
\text { design; and analysis or } \\
\text { interpretation of data }\end{array}$ \\
\hline $\begin{array}{l}\text { Hugh } \\
\text { Stephen } \\
\text { Markus, DM, } \\
\text { FMed Sci }\end{array}$ & $\begin{array}{l}\text { Department of Clinical } \\
\text { Neurosciences, University of } \\
\text { Cambridge, United Kingdom }\end{array}$ & $\begin{array}{l}\text { Drafting/revision of the } \\
\text { manuscript for content, } \\
\text { including medical writing } \\
\text { for content; study } \\
\text { concept or design; and } \\
\text { analysis or interpretation } \\
\text { of data }\end{array}$ \\
\hline $\begin{array}{l}\text { Anke Erma } \\
\text { Hensiek, } \\
\text { FRCP, PhD }\end{array}$ & $\begin{array}{l}\text { National Clinic for Ataxia } \\
\text { Telangiectasia. Papworth } \\
\text { Hospital NHS Foundation } \\
\text { Trust, Cambridge, United } \\
\text { Kingdom }\end{array}$ & $\begin{array}{l}\text { Drafting/revision of the } \\
\text { manuscript for content, } \\
\text { including medical writing } \\
\text { for content; study } \\
\text { concept or design; and } \\
\text { analysis or } \\
\text { interpretation of data }\end{array}$ \\
\hline
\end{tabular}

\section{References}

1. Tiet MY, Horvath R, Hensiek AE. Ataxia telangiectasia: what the neurologist needs to know. Pract Neurol. 2020;20(5):404-414.

2. Low A, Mak E, Malpetti M, et al. In vivo neuroinflammation and cerebral small vessel disease in mild cognitive impairment and Alzheimer's disease. J Neurol Neurosurg Psychiatry. 2021;92(1):45-52.

3. Scheltens $P$, Barkhof $F$, Leys D, et al. A semiquantitative rating scale for the assessment of signal hyperintensities on magnetic resonance imaging. J Neurol Sci. 1993;114(1) 7-12.

4. Cordonnier C, Potter GM, Jackson CA, et al. Improving interrater agreement about brain microbleeds: Development of the Brain Observer MicroBleed Scale (BOMBS). Stroke. 2009;40(1):94-99.

5. Lin DD, Crawford TO, Lederman HM, Barker PB. Proton MR spectroscopic imaging in ataxia-telangiectasia. Neuropediatrics. 2006;37(4):241-246.

6. Kamiya M, Yamanouchi $\mathrm{H}$, Yoshida $\mathrm{T}$, et al. Ataxia telangiectasia with vascular abnormalities in the brain parenchyma: report of an autopsy case and literature review. Pathol Int. 2001;51(4):271-276.

7. Lee YM, Koo HW, Kang HK, et al. The prevalence and characterization of cerebral microbleeds in young people having intracerebral hemorrhage. J Cerebrovasc Endovasc Neurosurg. 2018;20(2):112-119. 


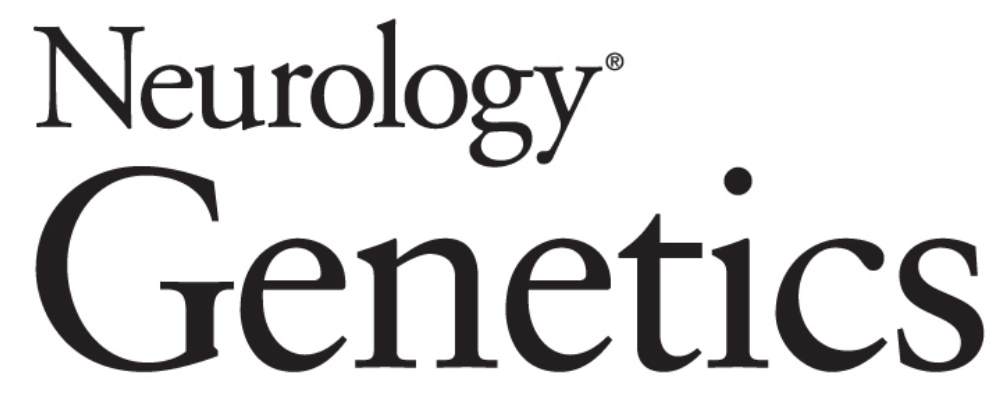

\section{White Matter Hyperintensities and Cerebral Microbleeds in Ataxia-Telangiectasia May Yung Tiet, Stefania Nannoni, Daniel Scoffings, et al. Neurol Genet 2021;7; \\ DOI 10.1212/NXG.0000000000000640}

This information is current as of November 30, 2021

$\begin{array}{ll}\begin{array}{l}\text { Updated Information \& } \\ \text { Services }\end{array} & \begin{array}{l}\text { including high resolution figures, can be found at: } \\ \text { http://ng.neurology.org/content/7/6/e640.full.html }\end{array} \\ \text { References } & \begin{array}{l}\text { This article cites } 7 \text { articles, } 3 \text { of which you can access for } \\ \text { http://ng.neurology.org/content/7/6/e640.full.html\#\#ref-list }\end{array} \\ \text { This article, along with others on similar topics, appears } \\ \text { following collection(s): } \\ \text { All Genetics } \\ \text { http://ng.neurology.org//cgi/collection/all_genetics } \\ \text { MRI } \\ \text { http://ng.neurology.org//cgi/collection/mri } \\ \text { Information about reproducing this article in parts (figures,t } \\ \text { its entirety can be found online at: } \\ \text { http://ng.neurology.org/misc/about.xhtml\#permissions } \\ \text { Permissions \& Licensing } & \text { Information about ordering reprints can be found online: } \\ & \text { http://ng.neurology.org/misc/addir.xhtml\#reprintsus }\end{array}$

Neurol Genet is an official journal of the American Academy of Neurology. Published since April 2015, it is an open-access, online-only, continuous publication journal. Copyright Copyright $\odot 2021$ The Author(s). Published by Wolters Kluwer Health, Inc. on behalf of the American Academy of Neurology.. All rights reserved. Online ISSN: 2376-7839.

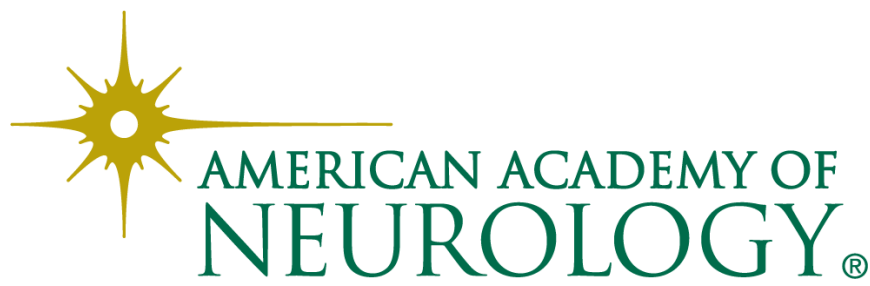

